\title{
上咽頭血管線維腫の放射線・ホルモン併用療法
}

\author{
森裕司・里見 文男* \\ 西村 善彦・雲井 健雄
}

\section{Radio and Hormone Therapy for Nasopharyngeal Angiofibroma}

\author{
Hiroshi Mori, Yoshihiko Nishimura and Takeo Kumoi \\ (Hyogo College of Medicine) \\ Fumio Satomi \\ (Hyogo Prefectural Hospital of Kaibara)
}

\begin{abstract}
We describe a 15-year-old boy, who presented with recurrent nasal bleeding. A diagnosis of nasopharyngeal angiofibroma (stage I) was made and, the tumor was excised by a transpalatal approach. Four months later, we found a recurrent tumor. Two months later, CT scan and NMR imaging revealed that it had extended into the temporal fossa and intracranially (stage IV). We thought conservative therapy would be much safer and more appropriate than surgery, hence he was treated with combinded irradiation $(3000 \mathrm{rad})$ and hormone (estrogen) therapy. The tumor was completely eradicated in 2 years. The place of surgical and radiotherapy in the management of juvenile angiofibroma is discussed.
\end{abstract}

Key words: nasopharyngeal angiofibroma, hormone therapy, irradiation therapy

\section{緒言}

上咽頭血管線維腫 (NA) は組織学的には良性 の腫瘍ではあるが，またその血管に富む特徵ゆ えに進行すると完全摘出が不可能なとともしば しば経験され臨床的には取り扱いに苦慮する腫 瘍である、極端な立場を取る人々では，NAの 進展度の尺度となるべき staging には余り重点 をおかず CT 画像や血管系の所見から切除可能 群と切除不能群とに分け, 一方は選択的塞栓術 から手術へ，他方では適当な放射線治療の道を 選ぶといったアルゴリズムをあげるあのもあ $る^{11}$. 手術的な完全摘出不能例に対する治療と
しては，前述の如く放射線治療が主体となるよ うであるが，その他にはホルモン療法も試みら れている.

NA 自体が頻度の少ない腫瘍であり, 従って 一施設で経験される症例屯少ないから，そこ から導かれる結論屯打のずから限界があるのは 当然といえるし，放射線治療一つを取っても Toronto グループ (Cummings たち2) のように 55 症例を初期治療として取り扱った経験と比較 すると少数例ではその価值む制限されることは 否めない，ただ今回私たちは，頭蓋内まで進展 した再発性のNAに対して放射線とホルモン剂 
との併用療法を行なって腫瘍は完全に消失し， 再発を認めていない症例を経験したのでNA 取 り扱いの原則を含めて考察したいと考光る.

\section{症例および経過}

症例は15才の男性で, 当科初翏の 3 力月前加 ら，たび重なる鼻漏を伴わない鼻出血を繰り返 して近医で処置を受けていたが，61年 7 月 9 日 の夜から翌朝まで大量の鼻出血をきたしたため 当科外来を受診して即時緊急入院した。 入院時 の鼻内所見では左総鼻道をほぼ充満するピンク 色の腫瘍が認められた，写真は左の鼻内所見を 示し，向かって右側には下鼻甲介，左側に一部 見えているのは鼻中隔であり矢印は腫瘍塊を示

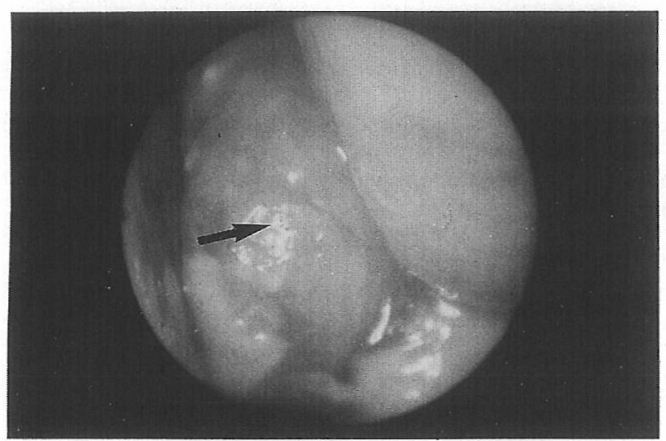

図1 中鼻甲介と鼻中隔の間に腫瘍が認められる (矢印)。

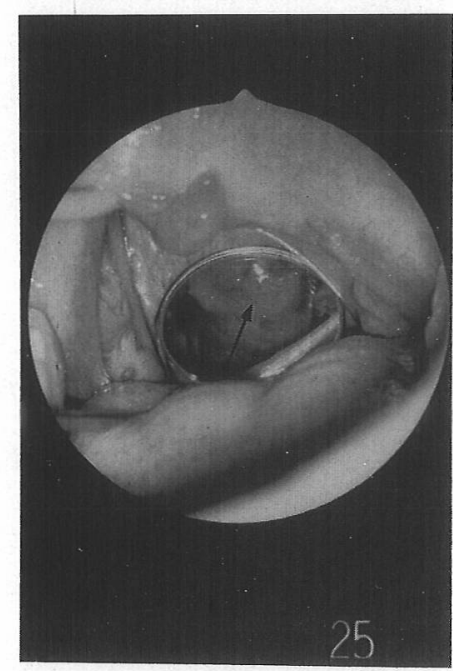

図2 鏡中央が腫痬である (矢印).

\section{している（図 1).}

後鼻鏡検査においても，表面に血管の走行す るピンク色の腫瘍が患側の耳管開口部に接する ように存在するのが確認できた，健側に下鼻甲 介の一部が観察できる(図 2 ).

単純X線写真 (Caldwell) では左鼻腔をほぼ 充満する陰影を認め，鼻中隔は健側へ圧排され て偏位しているのが観察される (図 3). CT 撮 影(水平断)では腫痬は上咽頭を充満し左鼻腔内 へ進展しているのが確認できる。図 4 の左側は 造影後の CT 画像であるが，良く enhancement されていて血管に富む腫瘍であることが推測さ れる，大後頭孔の前部に位置するのは後頭骨で あるが，腫瘍は後頭骨の前面より発生している あのと考えられた。また左上顎洞は腫瘍による 自然孔閉塞のために炎症性貯留液が存在する (図 4). 以上の所見加ら上咽頭血管繊維腫と 晾断し，易出血性のため生検は断念し，また staging でいうと stage I で手術的に摘出可能 と考えられたので腫瘍摘出術を行なうとととし た。

手術前に栄養動脈の確認と手術時の出血量の 減少とを期待してセルジンガー法による血管造 影を行ない，顎動脈がその主栄養動脈であるこ

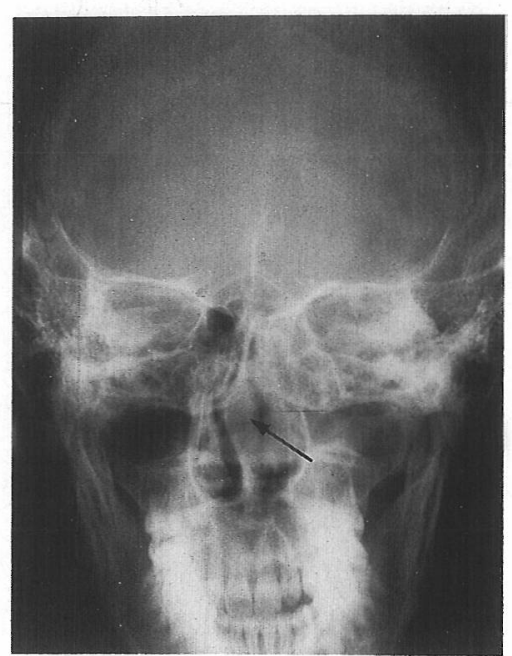

図 3 左鼻腔は腫瘍陰影で充満し鼻中隔は右側へ 圧迫偏位している (矢印). 
とを確認した後，ジェルフォームによる選択的 塞栓術を施工した。図 5 の左の写真は塞栓術前
を示し右の写真は顎動脈の塞栓術後の血管像で ある. 栄養動脈は良く塞栓され tumor stain む

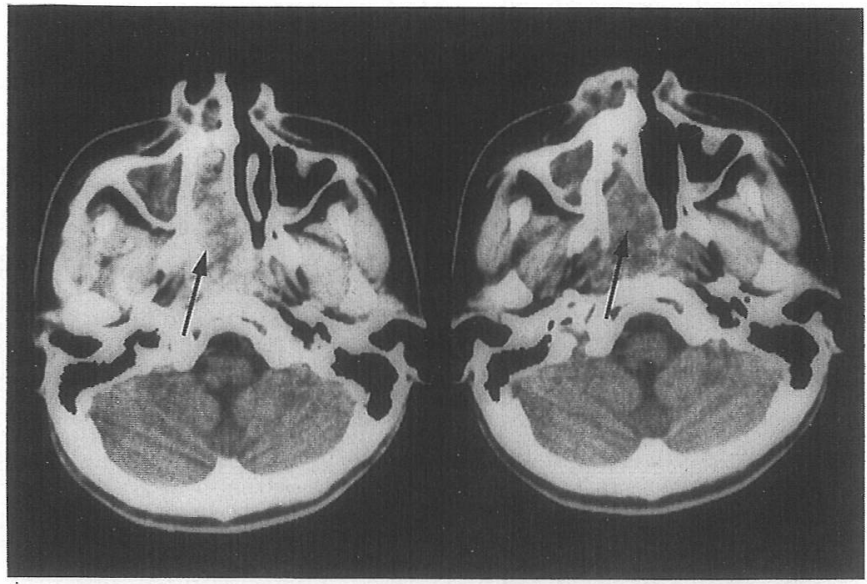

図 4 上咽頭より発生し鼻腔内へ突出している (矢印). 左 (造影), 右 (非造影) CT 画像

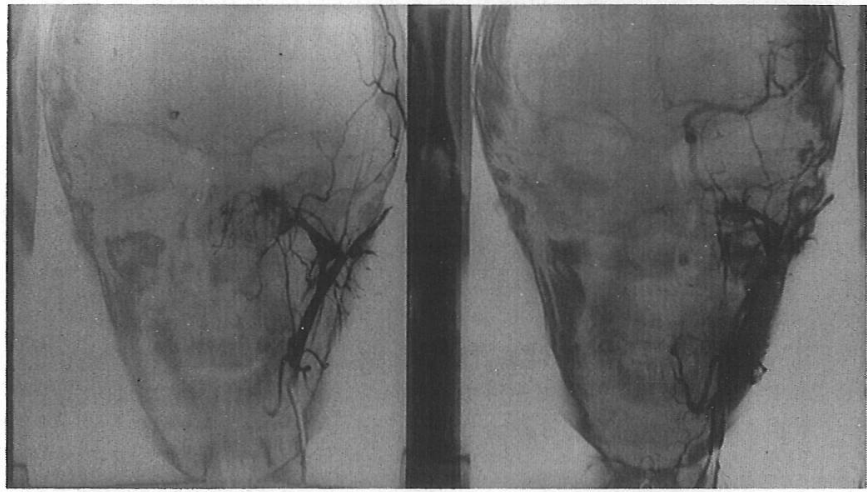

図 5 外頸動脈撮影，右図は塞栓術後

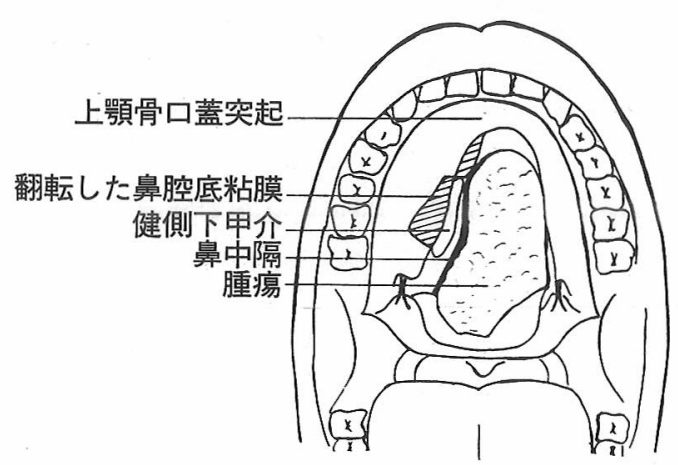

図 6 術中所見

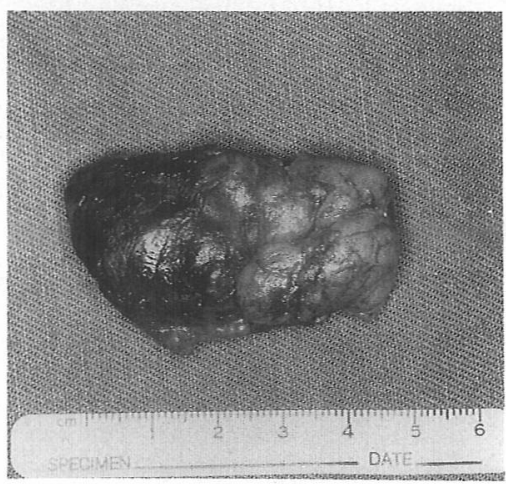

図 7 摘出標本 $55 \mathrm{~mm} \times 35 \mathrm{~mm}$ 
消失している(図 5 ).

手術は経口蓋法 (Dollance 切開) でアプロー

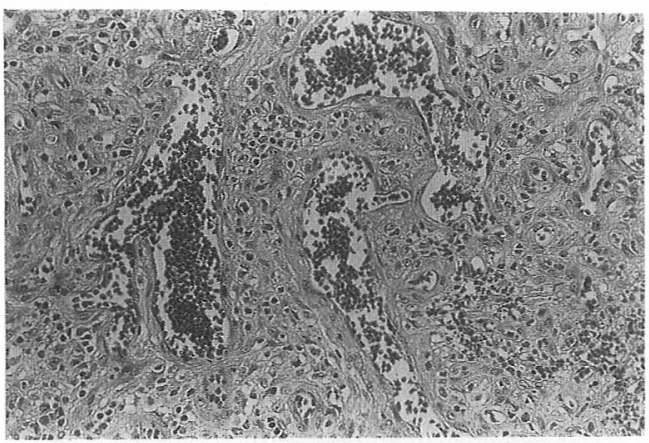

図 8 H. E. 染色 腫瘍は豊富な血管成分と fibroblast 様の間質成分よりなる。

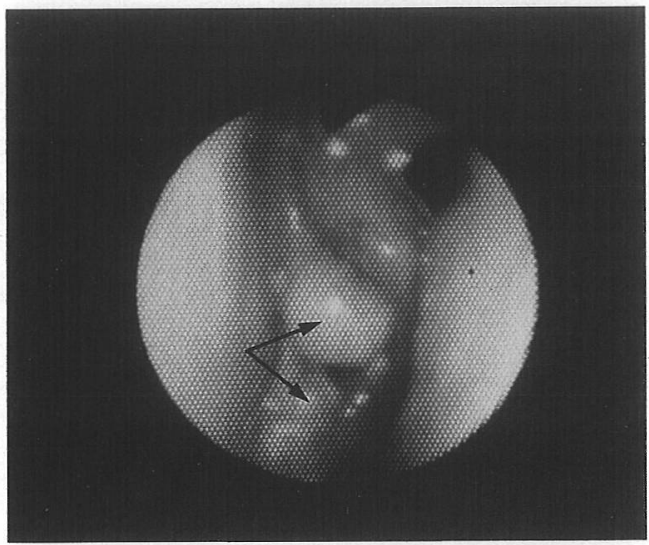

図 9 ファイバースコープによる鼻腔内所見 (矢印が腫痬).

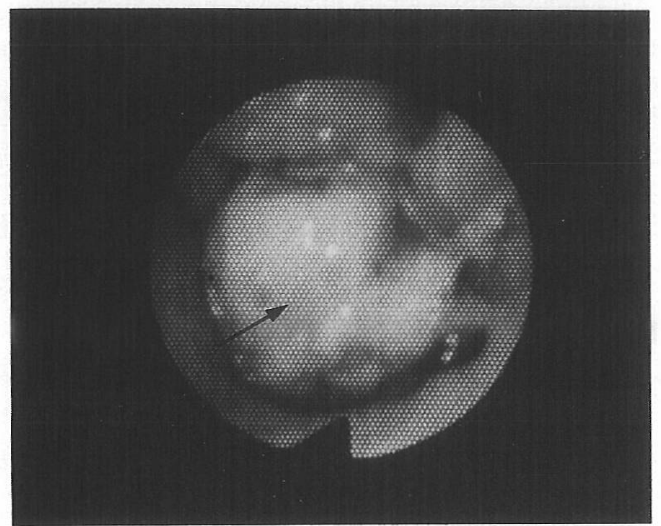

図10ファイバースコープによる上咽頭所見 (矢印が腫瘍)。
チし，蝶形洞前壁から後頭骨前面にかけて茎を 有していた腫痬を骨膜とともに一塊として摘出 した，図 6 はその模式図である。手術時の総出 血量は $700 \mathrm{ml}$ であったが腫瘍摘出時における 出血は約 $300 \mathrm{ml}$ で，顎動脈塞栓に伴う出血量 の減少は期待どおりであった。

摘出腫瘍は $5.5 \mathrm{~cm} \times 3.5 \mathrm{~cm}$, 重さ $13 \mathrm{gr}$ で あった（図 7).

腫瘍は豊富な血管成分と fibroblast 様の間質 成分とより成って扔り，術前診断と同様に組織 学的にも血管繊維腫と確認するととができた (図 8).

良好な術後経過をとって退院した後は外来 で，経過観察を行なっていたが，手術の 4 力月 後の受診時に左上咽頭の天蓋部に再発を認め た。

患者は当時期末テストの期間中であり，また

表 1 Session $^{3)}$ のステージ分類より改変

\section{I}

A：腫瘍は後鼻孔か上咽頭天蓋に限定している。

B：IA に加わるに1つ以上の副鼻腔に進展の 認められるもの。

II

A：蝶形口蓋孔を通じての側方への進展は軽度 で，加翼口蓋窩内側へ進展の認められる むの.

B ：翼口蓋窩を完全に占拠して上顎洞後壁を前 方へ圧排し，䫟動脈枝を外側及びまたは前 方へ偏位させている，時には眼䈑骨を破壊 している。

C：翼口蓋䆚から煩骨及び側頭窩へ進展してい る。

III 頭盍内に進展している。

表 2 アメリカ病期分類委員会案の Chandler ${ }^{4)}$ の 修正より改変

\begin{tabular}{|c|c|}
\hline 病 期 & 腫＼cjkstart瘍 局 \\
\hline I & 上咽 \\
\hline ПI & 鼻腔及び蝶形洞 \\
\hline III & $\begin{array}{l}\text { 節骨, 上顎洞，翼口盖腔，側 } \\
\text { 頭下窩，眼窩，類部 }\end{array}$ \\
\hline IV & 頭蓋内 \\
\hline
\end{tabular}


公立高校在籍中であったために出席日数の問題 から翌年の春休みまで再手術を行ないえない状 況にあった。

前鼻鏡所見，後鼻鏡所見において再発腫痬は 初診時とほぼ同等の大きさに見えたので再手術 は春休みまで待って，それまでは外来観察で良 いだろうと，安易に考えていたが（図 9，10），
再入院の術前評価としての CT および MRI 撮影で直視できない部位への進展範囲（翼口蓋 窩，側頭下窩，頭蓋内特に parasellar）が大き く，一期的に手術的完全摘出を行なうととが不 可能の状態にあるととが確認され，CT や MRI による術後の注意深い経過観察の必要性が痛感 された。

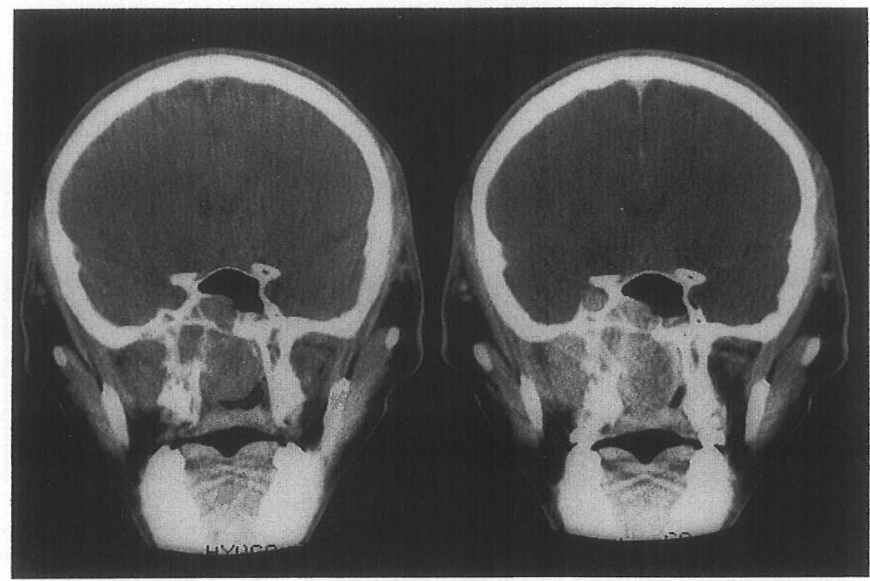

図11 左は単純 CT，右は造影 CT であるが腫瘍は側頭下窩を充満し一部頭蓋内に伸展している (後方から見ているので左右が逆).

表 3 治療経過表

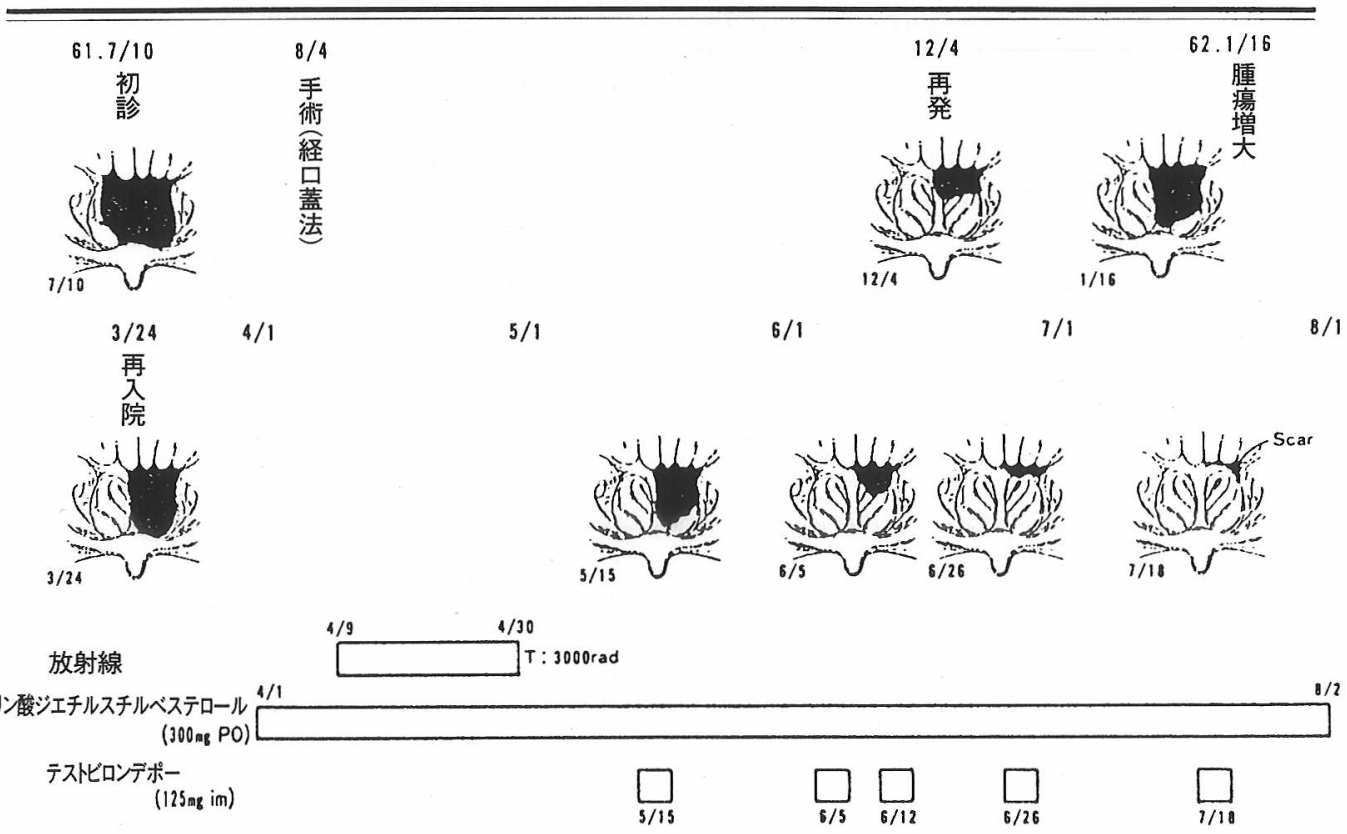


前額断 CT 所見では腫瘍は側頭下窩をほぼ充 満し，また enhancement CT では斜台，中頭 蓋䆚をこえ頭蓋内に進展しているのが確認でき る(図11：後方から見ているので左右が逆). 初診時には Session の stage 分類（表1) では stage I Aであったのが今回は stage III, Chandler の stage 分類では stage I から stage IV まで進展していると考えられた（表 2) ${ }^{3)}$ 4).

stage IV では，頭蓋内への浸潤が認められる
状態で，また栄養動脈として内頸動脈が関与し ている可能性が高く, 腫瘍を一塊として全摘出 するととは困難であり一般的には非手術的な治 療法が選択される。

保存的な治療のなかで一般的な方法は放射線 治療であり，Linac X 線で 30 Gy 程度の照射 が通常行なわれる.

また一方では NA が思春期の男性に好発し 22２3才以降に自然に消退するととから，古く よりホルモン療法む行なわれており, estrogen

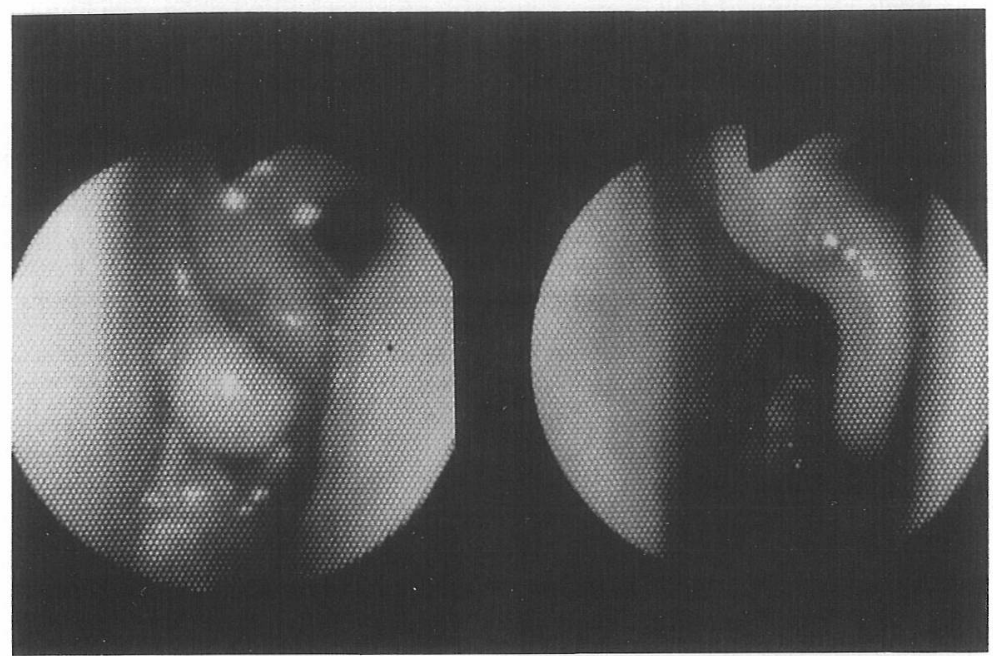

図12 治療前（左），治療後（右）の鼻腔内所見

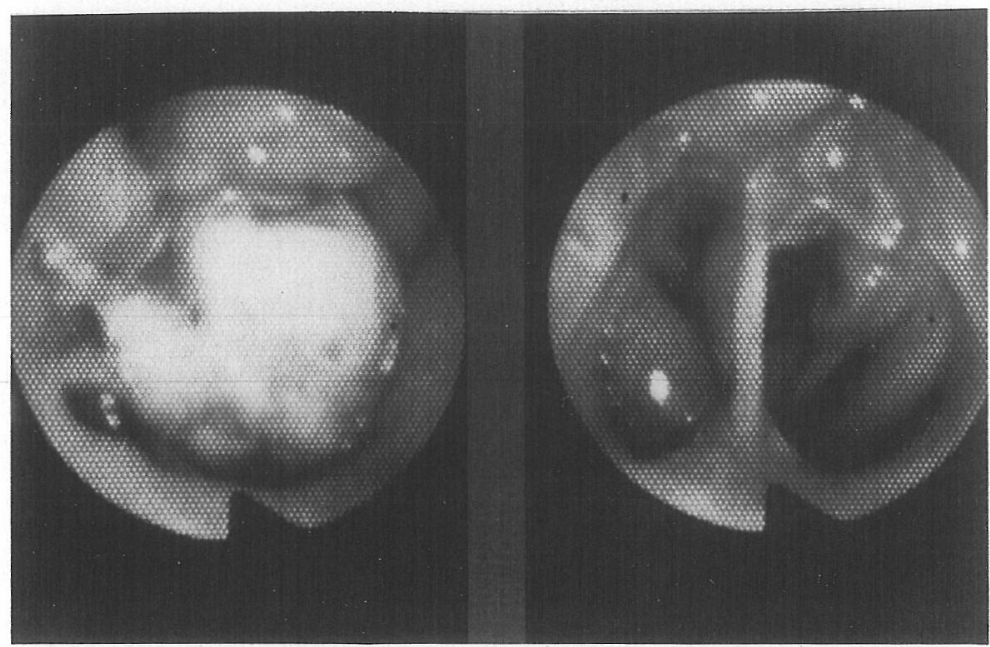

図13 治療前（左），治療後（右）の鼻腔内所見 
が NA の vascularity の減少，間質成分の成熟 を促すと報告され ${ }^{5)}$ ，術前処置として出血量减 少を目的として試夕られているが疑問視する文 献少なくない，また保存的な治療の際にも試 みられている。

一方には一部の報告では androgen によって 腫瘍が消失し， androgen 屯有効なホルモン療 法であるという意見もある6778).

最近では Mokhtan ら9) の報告で NA 中に androgen receptor が発見されており，NAの 発生にホルモンが密接に関係していることを示
すとともに，ホルモン療法の有効性を示唆する あのと考えられる。その他の一般的治療法とし ては凍結治療，電気燒灼などあ上げられるが必 ずしも効果は期待できない.

我々の症例であ先ず手術療法を考慮したが， 頭蓋内進展を認め，加つ海綿静脈洞の位置する ところにあって，手術操作の難度と危険性とを 考えて, estrogen によるホルモン療法と放射線 治療との併用療法を試みることとした。

治療経過を表 3 に示すが, estrogen としてリ ン酸ジェチルスチルベステロール（商品名; ホ

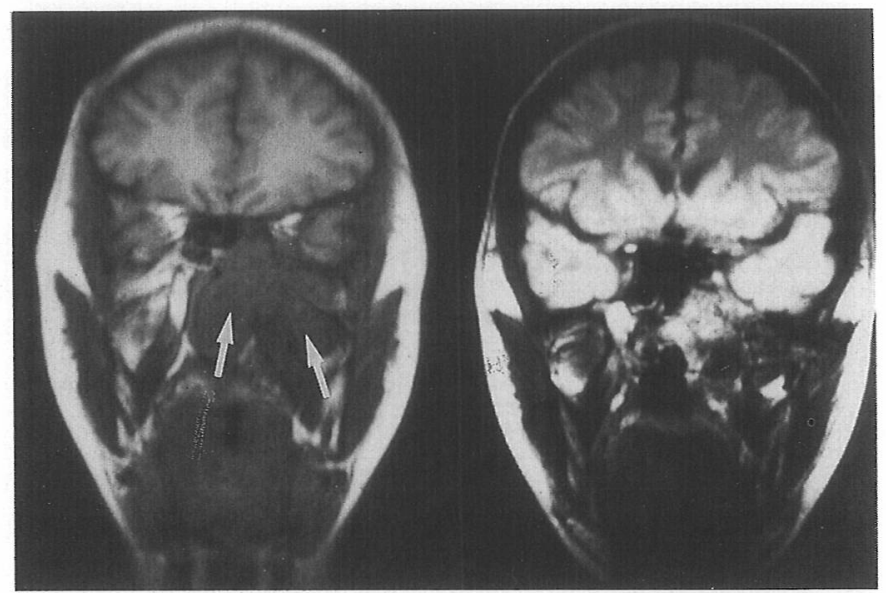

左; 治療前

右；治療後

図14 前額断 MRI. 治療前の腫瘍（矢印）は消失している.

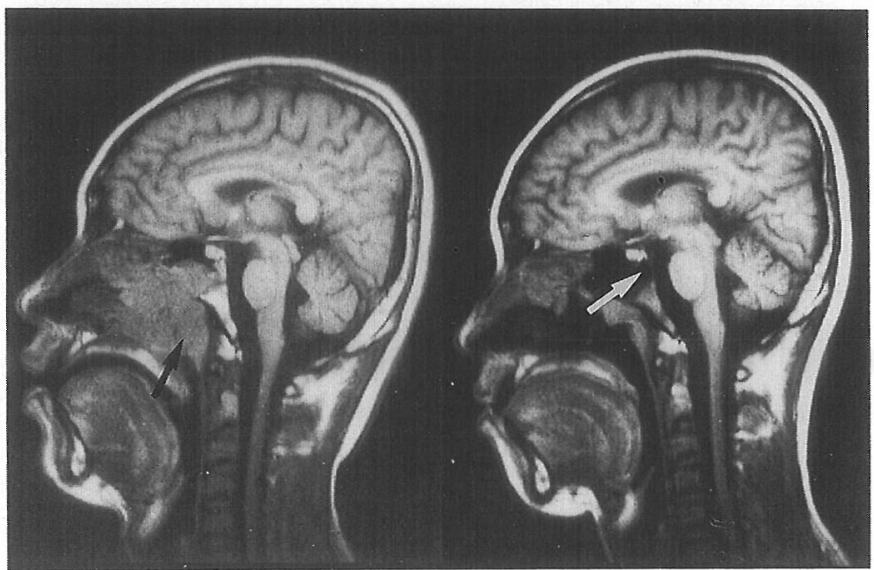

図15 治療前の腫瘍（矢印）は消失している。 また，後頭骨に骨欠損を認める（矢印）。 
ンバン $\left.{ }^{\circledR}\right) 300 \mathrm{mg}$ を連日経口投与で開始し，そ の 1 週後より Linac X 線を $200 \mathrm{rad} /$ 日で併用 した.

放射線は 4 月 9 日より 4 月 30 日まで総量 30 Gy 照射を行なった。

estrogen は 4 月 1 日より 8 月 2 日まで約 4 力 月間投与した。 ただ投与開始 1 力月目頃より, 患者から皮膚がスベスべになり髸がやや薄くな るという軽度の女性化の訴えがあったため， 5 月15日より 2 週間に 1 度の間隔で男性ホルモン であるテストビロンデポーの筋注を行なった。

腫瘍は照射終了後 2 週目頃上り縮少し始め約 2 力月目頃にはほぼ消失した。

図12，13はそれぞれ治療前後の鼻腔内所見と 上咽頭所見であるが，瘀痕のみを残し完全に消 失しているのが観察される.

また MRI の前額断及び矢状断においても治 療前の巨大な腫瘍，特に直接観察できない側頭 下窩の腫瘍む消失していることを証明している (図14，15).

現在約 2 年を経過しているが全く再発の兆し は認めていない。

\section{考案}

緒言でも述べたように，NA 自身が耳鼻咽喉 科外来でさほど一般的でない腫瘍であり，医師 自身が自ら経験する症例数む限定されている場 合には，一つの経験が次の症例に対処する道を 示唆してくれるとは言い難い，その上にNAの 病理像む以上の乙とを証明しており，本質的に は間質組織内に血管成分に富む組織があるのは 当然であるが，各成分の成熟度と量との配分は 各症例によって異なっており，Loven ${ }^{10)}$ は，才 スロー大学で1968年から1982年までの間に治療 を受け再発した NA 12症例を詳細に検討し， 再発を来した NA 症例の摘出標本で腫瘍に含 まれる血管を調査して，壁の薄い血管の占める 率と再発とが良く相関し，乙の因子（著者の表 現によれば volume density of the wall of thin -walled vessels) が $1 \%$ 以下 (less vasucular tumors を意味する)の場合には再発の可能性が
大きいという．従って1\%以上 (vasucular tumors）は再発しにくい訳である，実際には病理 像をくまなく調査するととはかなり根気を要す る仕事となるであろうし，危険を侵して生検を 行なってもその病像全体を予想することは困難 であろう。また一方では，前述の血管壁のとと ではなくて全体として血管成分に富む腫瘍であ れば，摘出手術に伴う出血量は多くても摘出術 そのものは比較的に容易であるが，反対に fibroangioma とあ呼ぶべき NA にあっては，手 術的には摘出は困難を伴うけれぞも摘出後には 再発は血管成分の少ないだけに余り多くない。 このように一つの経験が，次の症例への参考と なり得ない点で，NA の臨床的取り扱いの難し さが存在する. したがってNAに対する考え方 というあのを確立しておく必要性があるという べきで，これはNA のみには限るあのではない が，患者の最多数を占めるのは若い男性であり， その人の将来をむ見通した展望の上に立脚した 安全かつ確実な治療を心掛けるべきである. 文 献上には数回の手術的治療の後に再発して大量 出血で死亡した少年の例屯散見され，乙のよう な症例を経験した医師は夢魔に襲われるような 事態から，忼って消極的態度の主張屯聞かれ るのである. この意味においても NA は耳鼻咽 喉科医単独に取り扱う腫瘍というよりは，むし ろ脳外科，放射線科医師などとの共同目標之考 えたほうが良いであろう.実際に米国の UCLA の $\mathrm{Ward}^{11)}$ グループは過去 4 半世紀の間に，耳 鼻咽喉科医と放射線医との連携のもとに NA の60例以上に及ぶ経験を持ち，合理的な診断と 治療法とについて述べている，彼らの見解をま とめると次の如くである.

1）上咽頭に観察される NA は氷山の一角 にすぎず全体の病巣の広がりを類推できないて と.

2) 造影 CT 画像が真の病巣の広がりを知り 得る方法であり，また両側の内，外頸動脈血管 写が診断と治療とに必須であるとと.

3）前，中頭蓋窩への伸展や parasellar への 
進展例は摘出不能と考えるべきとと.

4）若年者については手術的摘出がよいが海 綿静脈洞に近接した NA などは放射線治療の 方を優先すべきこと.

5) 彼らの行なった放射線治療では大多数は 放射線に良く反応して, 完全消失あるいは気道 閉塞の緩解を見たとと.

6）最近の症例では栄養動脈の選択的塞栓に よって手術時の出血量の減少が見られたとと.

以上の如く NA の治療には，一貫した根本概 念が必要なととが理解されるであろうし，放射 線治療屯外科的切除屯殆ど同等に有効である が，そこにはある種の危険性をも伴うことは疑 いを入れない．また症例毎の NA の組織成分 にも依存する問題であるから，大胆に言えば 10 才以下の若年層の NA 患者はその腫瘍は放射 線に非常に鋭敏の故にこれを第一選択とすると いう哲学も成立する. 以下に NA の先ず各個的 問題を取り上げ，最後に以前の症例と今回の症 例とから我々の対処する考えを述べてみたい。

NA の病因についてはいまだに明らかではな いが，思春期の男性に好発し，また sexual maturity により自然退縮が認められることも あるので pituitary-adrenogenital system のホ ルモンのアンバランスがその病因ではないかと 推測されている. 事実 Jacobson ${ }^{12)}$ により頭蓋 内に進展した NA の自然退縮が報告されてお り，1 例の症例報告ではあるが NA の自然退 縮が CT 画像上で実証された貴重なものとい えよう。また先述したとおり最近の文献では, 腫瘍内に androgen receptor が確認されてお り, dihydrotestosterone と良く結合するため, NA は androgen dependent tumor であると報 告されている9.

NA は斜台より 発生するので，胎生期の頭 蓋後頭板 (basiocciput) の embryonic chondrocartilage の遺残から発生すると考えられてい るが，蝶形口蓋部の内翼突板または蝶形口蓋孔 から発生するとの見解もあり, Spector ${ }^{13)}$ は自 験例からとの後者の方があっとも可能性がある
という. 本症例では写真15の MRI の矢状断に 見るように，後頭骨加ら発生し上咽頭腔に進展 しているのが観察され，また，治療後の写真で あ後頭骨の骨欠損が最も著明であることから， 本症例では前者よりの発生を示すすのと思わ れる。

治療に関しては，屯し手術的に摘出可能と考 えられたならば手術法として, 各 stage ごとに 区別して考えられるべきである.

Spector は過去 20 年間の 57 例のまとめと自験 28例の経験から各 stage 毎に自ら行なったアプ ローチを紹介している（表 4). しかし彼の見解 では stage 自体が意志決定に必ずしも有用では なく，NA の進展方向や進展度によるべきとと を強調している．そして画像診断的には CT よ りあ MRI が最善であると述べており，ての点 については本症例でも私たちの感じたところで あって異論がない，そして手術を行なうにあた っては潅流動脈の塞栓に続く手術治療を推す報 告屯多(14) 16).

Bremer ${ }^{16)}$ の報告は40年間の 150 例に及ぶ症例 からの経験であってなかなか説得力がある. 彼 らは前期（1945～1955）は放射線治療，中期 （1955～1971）では主として手術 (lateral rhinotomy aproach)，(1971～1983）ではすべて手 術療法で処置されたと述べ，手術法としては種 種の拡大方法を含めて lateral rhinotomy が頭

表 4 Spector ${ }^{13)}$ の NA の病期分類と手術的 アプローチより改変

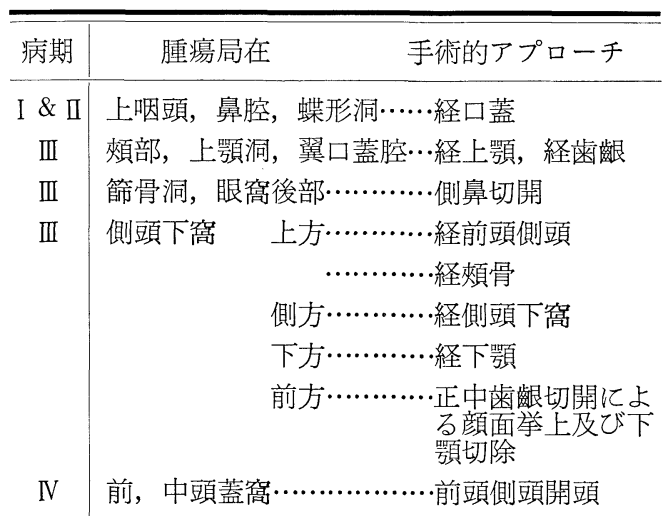


蓋底，側頭窩及び側頭下窩などまでも明視下に 掞いて NA 摘出に有利であると述べている.

Antonelli ら ${ }^{14)}$ は, stage I では suprahyoid pharyngotomy, stage I， IIIでは lateral rhinotomy approach で，むし側頭下窩への進展が 認められれば, midface degloving と transzygomatic approach との併用を推奖しており, stage IVでは脳外科との合同で frontotemporal approach で手術するのが安全であると報告し ている. 最近の手術器具の改良と手術手技の向 上によって頭蓋内進展の NA あ手術可能性が 拡大している(例えば Fisch ${ }^{17)}$, Standefer ${ }^{18)}$ ).

しかし NA の進展範囲があまりにあ大きく， また危険区域に近接して全摘出することが困難 な場合にはいろいろな保存的療法が試みられて いる。

今日まで最む一般的に行なわれ，かつ最も効 果を上げているのは，放射線治療であり，逆に 乙れを第一義的に主張する人々あある，総線量 に関しては様々であるが，Toronto グループの Cummings $^{2)}$ 及び Edinburgh の Sinha ${ }^{19)} の$ philosophy では 3 週間に 3000-3500 rad dose が原則である. Toronto グループでは $30 \mathrm{~Gy}$ で 制御率は 80\%(32/40), 35 Gy で 80\%(12/15) と 同率であり，腫瘍が大きいほど照射量も増すと は考えておらず，とにかく小線量で良いとのと とである. このグループより症例数は少ないが， $4500 \mathrm{rad} ， 4.5$ 週照射後に再発した症例の報告 (Ward ${ }^{11)}$ 1983) あある. 大線量を照射した場合 には，特に後発する白内障や，骨変形のような 重篤な副作用も報告されていて7)，また放射線 誘発癌も考慮すれば現在では当症例に施行した $3000 \mathrm{rad}$ 程度の小線量が一般的であろう. 放射 線の治療効果に関しては早いものでも照射後 1 〜 5 力月頃より縮少し始め，消失までに 6 力 月から 1 年程度の日数を要するとの報告が多 (20).

Toronto グループ Cummings の NA に対 する一貫する哲学は，放射線治療が手術的治療 よりもより有効であるからではなくて，摘出術
とほぼ同格ではあるが，より深刻な危険の少な い点で推奨しているのである，過去の報告での 放射線誘発の上顎癌などは彼のシリーズには認 められず，彼は 1 例だけ散乱放射線による甲状 腺癌を経験しているのみである.

放射線治療のほかにはホルモン療法が古くか ら行なわれてはいるが，未だ統一された意見は なく試行錯䛊の状態である. Martin ら ${ }^{6)}$ は， NA 患者の尿中の $17-\mathrm{KS}$ や 17-OHCS など に異常を認めるような明らかに sexual development の遅延しているような症例に対しての み，ホルモン療法を行なうべきであると述べて いるが，一方で，Henderson ら ${ }^{21)}$ はホルモン 異常を認めない症例でも estrogen や androgen の著効した症例屯報告しており，ホルモン異常 のみが選択基準ではないてとを証明していると 考えられる。他方ホルモン療法に対する厳重な 戒めむ存在する。成人では, 特に 9 才から 15 才 の間の男性では辠丸機能の成熟期にあたるため に ethinyl estradiol の 1 日量 $1 \mathrm{mg}$ (stilbestrol の $2 \mathrm{mg}$ 亿該当）は，1 カ月投与で睪丸萎縮を きたすとも言われていてWard ${ }^{11)}$ はホルモン単 独療法は有効ではないと述べ，また術前処置と しての効果にも限界のあることを強調してい る. 本症例でも 17-KS や 17-OHCS には異常 を認めなかったが， estrogen の一種であり， anti-androgene 作用の強いリン酸ジエチルスチ ルベステロール（商品名；ホンバン®）を放射 線と併用し，ホルモン療法単独の効果は確認す ることができなかったものの, 照射直後より腫 瘍は縮少し始め，2 力月目には完全に消失した ことが，諸家の放射線単独治療の報告における 効果発現時期および消失するまでの期間より短 かったととを併せ考えると， estrogen は有効な 治療補助手段であったととを示唆する結果であ ると考えられる。

また，先述したとおり NA は sexual maturityにより自然に消退することああって ${ }^{12)}{ }^{22)}$ ， 全摘出を考えるよりその大きさを維持しておい て，自然に消失するのを待つの屯最屯自然な 
治療法のひとつであるとの少数意見あある. Spector ${ }^{13)}$ の27自験例で 1 例だけ頭蓋内に伸展 する巨大腫瘍で，手術に応じなかった症例に対 して放射線治療と estrogen 治療とで有効であ った症例が含まれており 2 年後の経過観察でも 再発は見られないという。

一般診療に拈いての注意点としては，NA は 10才から18才の青年期の男性に好発し，乙の頃 の男性は NA が存在しなくても，例えばアレ ルギー性鼻炎に伴う鼻出血などの特発性鼻出血 を来しやすい時であある，また患者自身む度重 なる出血のたびにティッシュペーパーなどを鼻 腔内に插入しているため，キーセルバッ八部位 などがビラン状になっているととが多く，その 部分が出血点であると早とちりしてしまうこと ああり，そのために小さい NA の場合，一般 の診療では見逃されるととも考えられる。ゅえ に度重なる出血を主訴に受診した青年期の患者 に対しては現在では fiber scopy なども発達し ていて反射の強い患者に対しても容易に上咽頭 の観察ができるようになっているので上咽頭の 観察は励行すべき手技であると考えられる.

\section{結語}

頭蓋内に伸展した進行性 NA に対して放射 線療法とホルモン療法の併用により良好な結果 を得たので報告した.

また，私たちの NA に対する考えを簡単に まとめれば, stage I, 【では塞栓術と手術と を第 1 選択とし， stage IIIでは MRI，CT を参 考として塞栓術と手術併用を第一選択とする が，NA の進展方向などからアプローチの方法 には特に深い考慮が必要であり，手術の危険性 とひきくらべて本例のような放射線とホルモン 療法の併用屯考えても良いのではなかろうか. stage IVでは脳外科との共同作業が必要であり, 屯し患者の理解の得られないときには，放射線 とホルモン療法を実行するのが良いであろう.

\section{参考文献}

1) Ward PH : Place of radiotherapy in the management of juvenile angiofibroma. Dilemmas in otorhinolaryngology (ed by Harrison DFN). pp 229 232, Churchill Livingstone, Edinburgh, 1988.

2 ) Cummings BJ, Blend R, Keane $T$, et al : Primary radiation therapy for juvenile nasopharyngeal angiofibroma. Laryngoscope 94 : 1599 1605, 1984.

3) Session RB, Bryan RSM, Naclerio R, et al : Radiographic staging of juvenile angiofibroma. Head and Neck Surg 3:279 283, 1981.

4) Chandler JR, Goulding R, Moskowitz L, et al: Nasopharyngeal angiofibromas staging and management. Ann Otol Rhinol Laryngol 93 : 322 329, 1984.

5) Schiff M: Juvenile nasopharyngeal angiofibroma; a theory of pathogenesis. Laryngoscope $69: 981 \sim 1016,1959$.

6) Martin H, Ehrlich HE and Abels JE : Juvenile nasopharyngeal angiofibroma. Ann Surg 127: 513 536, 1948.

7 ）竹林脩文, 屋敷建夫, 野田益弘, 他：若年性鼻咽 腔血管線維腫症例とその治療法の検討. 耳喉 44: 201 208, 1972.

8 ）古市暢夫, 金森邦彦, 大藤周彦, 他：鼻咽腔血管 線維腫症例追加一男性ホルモン投与と病理組織所 見一. 耳喉 $45: 91 \sim 96,1973$.

9) M Mokhtan Farag, Ghanimah SE and Saleem TH : Hormonal receptors in juvenile nasopharyngel angiofibroma. Laryngoscope $97: 208 \sim$ 211, 1987.

10) Loven JO, Boysen $M$ and Kreybergs : morphometric analysis of nasopharyngeal angiofibroma. J Otolaryngol $16: 1 \sim 4,1987$.

11) Ward PH : The evolving management of juvenile nasopharyngeal angiofibroma. Brit J Laryngol Otol $8:$ 103 104, 1983.

12) Jacobson M, Petruson B, Ruth $M$, et al : Involution of juvenile nasopharyngeal angiofibroma with intracranial extension. Arch Oto $\mathrm{H} \& \mathrm{~N}$ Surg $115:$ 238 239, 1989.

13) Spector JG : Management of juvenile angiofibroma. Laryngoscope $98:$ 1016 1026, 1988.

14) Antonelli AR, Cappiello J, Lorenzo DD, et al : Diagnosis, staging, and treatment of ju- 
venile nasopharyngeal angiofibroma (JNA). Laryngoscope $97:$ 1319 1325, 1987.

15) Duvall AJ and Moreano AE: Juvenile nasopharyngeal angiofibroma; diagnosis and treatment. Otolaryngol Head Neck Surg 97 : 534 540, 1987.

16) Bremer JW, Nell HB, Desanto LW, et al : Angiofibroma-treatment trends in 150 patients during 40years. Laryngoscope $96: 1321 \sim 1329$, 1986.

17) Fisch $U:$ The infratemporal fossa approach for nasopharyngeal tumors. Laryngoscope $93: 36 \sim$ 44, 1983.

18) Standefer J, Holt GR, Brown WE Jr, et al : Combined intracranial and extracranial excision of nasopharyngeal angiofibroma. Laryngoscope $93: 772 \sim 779,1983$.

19) Sinha PP and Aziz: Juvenile nasopharyngeal angiofibroma ; a report of seven cases. Radiology $127: 501 \sim 505,1978$.

20）増田胤次，切替一郎：鼻咽腔線維腫（Nasenrachenfibrom) 並二鼻咽腔二発生セル血管腫ノ放射 線療法知見補遺. 大日耳鼻 $50: 348 \sim 373,1944$.

21) Henderson GP, Patterson $\mathrm{CN}$ and Durham NC: Further experience in treatment of jevenile nasopharyngeal angiofibroma. Laryngoscope $79:$ 561 580, 1969.

22) Hollender AR : Juvenile nasopharyngeal angiofibroma. The pharynx, basic aspects and clinical problems. pp 444 451, The year book publisher Inc, chicago, 1953.

$\left(\begin{array}{l}\text { 原稿採択 : 平成元年 } 4 \text { 月 } 5 \text { 日 } \\ \text { 別刷請求先 : 森 裕司 } \\ \text { 个6 } 63 \text { 西宮市武庫川町 } 1-1 \\ \text { 兵庫医科大学耳鼻咽喉科学教室 }\end{array}\right)$ 